\title{
PHYSOSTIGMINE REVERSAL OF POSTOPERATIVE SOMNOLENCE
}

\author{
Gary E. Hill, Theodone H. Stanley, and Craig R. Sentker
}

Physostigmine has been reported to be of value in reversal of somnolence induced by the anticholinergics, ${ }^{1,2}$ neurolept anaesthetics, ${ }^{3}$ and a large number of unrelated psychotropic agents.,5 This apparent non-specific reversal of central nervous system depressant drug action prompted us to consider whether physostigmine would also reverse post-operative somnolence induced by general anaesthesia and would, therefore, shorten the post-operative recovery period. Because halothane is a commonly used inhalation anaesthetic, this agent was chosen to evaluate the effect, if any, of physostigmine on post-operative somnolence induced by general anaesthesia.

\section{METHOD}

A total of 230 patients between 17 and 54 years of age were studied. All were ASA physical status 1 or 2 and were undergoing elective surgical procedures. They were premedicated with atropine sulfate $0.4-0.5 \mathrm{mg}$ and secobarbitone $1 \mathrm{mg} / \mathrm{kg}$ intramuscularly 30 minutes before the estimated anaesthetic induction time. Upon arrival in the operating area, an intravenous infusion was begun and routine monitoring equipment (precordial stethoscope, blood pressure cuff and electrocardiogram) was applied. All patients were induced with sodium thiopentone $3-5 \mathrm{mg} / \mathrm{kg}$ intravenously and anaesthesia was maintained with 50 per cent nitrous oxide in oxygen plus halothane. The inspired halothane concentration was maintained between 0.75 and 1.5 per cent. All patients studied received this concentration of halothane for not less than 45 minutes but not more than 90 minutes. No patient received muscle relaxants (except succinylcholine to allow tracheal intubation) or narcotic supplementation to the halothane-nitrous oxide-oxygen anaesthetic. At the end of operation all patients were taken directly to the post-anaesthetic recovery room. Those patients who responded to verbal command on arrival and those patients who required narcotic analgesics at any time in the recovery room were excluded from the study.

The remaining patients were immediately evaluated by the attending anaesthesiologist and an independent observer (designated recovery room personnel) for somnolence and orientation on a $0-4$ scale as has been previously described ${ }^{3}$ as follows: $4=$ unresponsive to verbal command and painful (pinprick) stimulation; $3=$ responds to painful stimulation but not to verbal command; $2=$ responds to verbal command and painful stimulation but is disoriented and does not initiate conversation; 1 = responds to all forms of stimulation, is well oriented but feels sleepy and does not initiate conversation; $0=$ oriented and initiates conversation.

Gary E. Hill, M.D., Assistant Professor, Theodore H. Stanley, M.D., Associate Professor, Craig R. Sentker, B.S., Research Systems Analyst, Department of Anaesthesiology, the University of Utah College of Medicine, 50 North Medical Drive, Salt Lake City, Utah 84132.

707

Canad. Anaesth. Soc. J., vol. 24, no. 6, November 1977 
TABLE I

\begin{tabular}{lcc}
\hline \hline & Group A & Group B \\
\hline Age (years) & $36 \pm 18$ & $33 \pm 16$ \\
Weight (kg) & $58 \pm 22$ & $61 \pm 16$ \\
$\begin{array}{l}\text { Duration of halothane (min) } \\
\text { Average inspiratory }\end{array}$ & $69 \pm 21$ & $73 \pm 14$ \\
$\quad$ concentration (\%) & $1.25 \pm 0.4$ & $1.20 \pm 0.3$ \\
\hline
\end{tabular}

After the initial evaluation, the attending anaesthesiologist randomly assigned the patient to one of two groups. Patients in Group A received physostigmine $2 \mathrm{mg}$ intravenously within one minute of the initial evaluation, while Group B received $2 \mathrm{ml}$ of saline intravenously. The recovery room personnel administering the medication did so in a blind fashion with the same personnel making repeated evaluations at $5,15,30,60,120$ and 180 minutes after the initial evaluation.

\section{Results}

One hundred and eighty-seven patients fulfilled the criteria for inclusion in the study; 100 patients in Group A, 87 patients in Group B. There were no significant differences in the ages, weights or in the total dose of halothane they received (Table I).

Eighty-four per cent of patients in Group A and 86 per cent of those in Group B were totally unresponsive (somnolence level 4) upon entrance to the recovery room. The remaining patients in both groups were at somnolence level 3 when they entered the recovery room (Table II). Five minutes following physostigmine administration, 16 per cent of Group A were in somnolence level 3,53 per cent in level 2, 28 per cent in level 1 and 3 per cent were completely awake (somnolence level 0 ). Ninety per cent of Group B patients were still in somnolence levels 3 and 4 five minutes after saline administration.

Fifteen minutes after physostigmine administration, 39 per cent of Group A patients were at level 0 , while no patients in Group B were classed at that level. After 60 minutes, 69 per cent of Group A were at level 0 while the remainder were at level 1. Only 38 per cent of Group B were at level 0 after one hour, while 54 per cent were at level 1,5 per cent at level 2 and 3 per cent were still at level 3 at this time.

No patient in Group A slipped back to a more somnolent level after physostigmine administration. No patient in either group was released from the recovery room until level 0 or 1 was achieved. The average time to achieve level 0 for Group A was 41 minutes and for Group B 59 minutes. The difference between the two groups is statistically significant, $\mathrm{p}<0.05$ (Student's paired t-test).

\section{Discussion}

Prolonged awakening occasionally complicates the immediate post-operative course following an otherwise uneventful general anaesthetic and operation. An agent that could shorten the awakening process would be very useful. Physostig- 
HILL, et al.: REVERSAL OF ANAESTHETIC SOMNOLENCE

TABLE II

Number of Patients at Each Somnolence Level vs Time*

\begin{tabular}{|c|c|c|c|c|c|}
\hline \multirow[b]{2}{*}{ Time } & \multicolumn{5}{|c|}{ Somnolence level } \\
\hline & 4 & 3 & 2 & 1 & 0 \\
\hline \multicolumn{6}{|l|}{$\begin{array}{l}\text { On arrival in } \\
\text { recovery room }\end{array}$} \\
\hline Group A (physo) & 84 & 16 & 0 & 0 & 0 \\
\hline B (saline) & 72 & 15 & 0 & 0 & 0 \\
\hline \multicolumn{6}{|l|}{5 minutes } \\
\hline Group A & 0 & 16 & 53 & 28 & 3 \\
\hline & 11 & 68 & 8 & 0 & 0 \\
\hline \multicolumn{6}{|l|}{15 minutes } \\
\hline Group A & 0 & 0 & 15 & 46 & 39 \\
\hline B & 0 & 13 & 59 & 5 & 0 \\
\hline \multicolumn{6}{|l|}{30 minutes } \\
\hline Group A & 0 & 0 & 4 & 42 & 54 \\
\hline B & 0 & 4 & 55 & 16 & 12 \\
\hline \multicolumn{6}{|l|}{60 minutes } \\
\hline Group A & 0 & 0 & 0 & 31 & 69 \\
\hline B & 0 & 3 & 4 & 47 & 33 \\
\hline \multicolumn{6}{|l|}{120 minutes } \\
\hline Group A & 0 & 0 & 0 & 16 & 84 \\
\hline B & 0 & 0 & 5 & 44 & 38 \\
\hline \multicolumn{6}{|l|}{180 minutes } \\
\hline Group A & 0 & 0 & 0 & 0 & 100 \\
\hline B & 0 & 0 & 0 & 42 & 45 \\
\hline
\end{tabular}

mine has been reported to be effective in reversing somnolence induced by droperidol, the anticholinergics, tricyclic antidepressants and phenothiazines. This study demonstrates that physostigmine is also useful in reversing post-operative somnolence after general anaesthesia. Our results demonstrate that 84 per cent of Group A patients who were initially unresponsive to verbal command or painful stimulation were responsive to these stimuli within five minutes after physostigmine administration. The patients who did not receive physostigmine were only slightly changed at five minutes. At 15 minutes, 85 per cent of those receiving physostigmine were responding to all stimuli and were well oriented, while only five patients ( 5.7 per cent) of the control group were so inclined. The remainder of the physostigmine group were more responsive than the control group at all subsequent evaluation times as well ( Table II).

Acetylcholine $(\mathrm{ACh})$ is considered an important transmitter in the cortical arousal system, ${ }^{8}$ but its exact role in central neurotransmission is unclear. Halothane and other general anaesthetics decrease synaptic transmission in autonomic ganglia. ${ }^{7,8}$ It has been suggested that the mechanism of this depression is through alteration of $\mathrm{ACh}$ release or binding at the $\mathrm{ACh}$ receptor. Physostigmine is a 
tertiary amine and thus easily crosses the blood brain barrier. ${ }^{9}$ Therefore, by increasing central ACh levels, physostigmine theoretically should increase ACh concentrations at central nervous system synapses and improve central neurotransmission. Our results in this study are consistent with this postulated mechanism.

Cholinergic side-effects such as bradycardia, nausea, vomiting and bronchospasm were minimal in this study. Ten patients developed nausea and abdominal cramps. Bradycardia (defined as heart rate less than 50/minute) was not seen. These side-effects are potentially serious enough, however, to demand careful monitoring.

\section{SumMarY}

The effects of physostigmine on reversal of post-operative somnolence following general anaesthesia were evaluated in 187 patients. Significant reversal of anaesthetic-induced post-operative somnolence was observed in those patients receiving physostigmine when compared to a control group. These results suggest that general anaesthesia with halothane may be included in those situations where central nervous system depression may be reversed by administration of physostigmine. Cholinergic side-effects observed with physostigmine administration were minimal.

\section{RÉSUMÉ}

L'influence de la physostigmine sur l'éveil de l'anesthésie a été évaluée chez cent patients en bonne santé (classe I - ASA). Comparés à un groups contrôle de 87 malades, les patients ayant reçu de la physostigmine ont résupéré plus rapidement de l'état de somnolence secondaire à l'anesthésie générale.

Ces résultats suggèrent que la physostigmine peut renverser l'état de somnolence secondaire à une anesthésie générale.

\section{ACKNOWLEDGEMENTS}

The authors thank the Recovery Room personnel at the University of Utah Medical Center for their assistance and Mrs. Vicky Larsen for manuscript preparation.

\section{REFERENCES}

1. Rumack, B.H. Anticholinergic poisoning: treatment with physostigmine. Pediatrics 52: 449 (1973).

2. Heiser, J.F. \& Gillin, J.C. The reversal of anticholinergic drug-induced delirium and coma with physostigmine. Am. J. Psychiatry 127: 1050 (1971).

3. Bidwai, A.V., Connelius, L.R., \& Stanley, T.H. Reversal of innovar-induced postanesthetic somnolence and disorientation with physostigmine. Anesthesiology 44 : 249 (1976).

4. Slovis, T.L., OtT, J.E., Teitelbaum, D.T., \& Lipscomb, W. Physostigmine therapy in acute tricyclic antidepressant poisoning. Clin. Tox. 4: 451 (1971).

5. El-Yousef, M.K., Janowsky, D.S., Davis, J.M., \& Sekerke, H.J. Reversal of antiparkinsonian drug toxicity by physostigmine: a controlled study. Am. J. Psychiatry 130: $141(1973)$. 
6. Hebs, C. CNS at the cellular level: identity of transmitter agents. Ann. Rev. Physiol. 32: $165(1970)$.

7. Chalazonitrs, N. Selective actions of volatile anesthetics on synaptic transmission and autorhythmicity in single identifiable neurons. Anesthesiology 28: 111 (1967).

8. LarrabeE, M.G. \& Posternak, J.M. Selective action of anesthetics on synapses and axons in mammalian sympathetic ganglia. J. Neurophysiol. 15: 91 (1952).

9. BrEBnER, J. \& HADLEY, L. Experiences with physostigmine in the reversal of adverse post-anesthetic effects. Canad. Anaesth. Soc. J. 23: 574 (1976). 